\title{
INITIAL APPRAISAL OF BUILDING DAMAGE IN INANGAHUA
}

\author{
B. H. Falconer*
}

\section{Introduction}

From aerial reconnaissance late on the morning of the earthquake, it was clear that severe damage to buildings had occurred at the township comprising Inangahua Camp and Inangahua Junction; and in farmland within a radius of five to eight miles.

Within that area, secondary effects of earthquake, visible from the air, included:- conspicuous cracks in the ground, small craters from sand ejected to the surface of pasture on low lying river terraces, a variety of landslides, collapses of domestic chimneys, partial collapses of tile roofs of dwellings, and timber frame dwellings moved on or moved off their foundations. This indicated in the Modified Mercalli scale, 1956 version, a felt intensity of M.VIII to MM $x$ in the epicentral region.

Correspondingly, it was considered to be probable that severe internal damage had occurred to dwellings, and also to furnishings, furniture and personal possessions, as the incidence of that type of damage could be expected at lower MoM. intensity ratings。

On the day of the earthquake, the author (in company with Mr GoJ. Lensen - vide earlier paper) concentrated firstly upon obtaining an overall appreciation of damage in and about the epicentral region and through the nearby centres of population, and secondly in despatching immediate reports. Thirdly, it was hoped to enter the area of prime damage on foot before nightfall, but the loss of all accesses for vehicles, on the three surface routes from Murchison, Westport and Reefton, combined with absence of a close landing strip for light aircraft, prevented that. All available helicopters, naturally, were committed by the civil defence organisations to the prime immediate task of search and rescue and to the evacuation of people from Inangahua.

Through the courtesy of the Inangahua County Civil Defence Controller, Mr T.E. Moore, the author joined an Air Force Iroquois helicopter in Reefton at first light on the day following the earthquake, and was set down at Inangahua Camp for an exploration on foot. He then contracted with a pilot of Helicopters N.Z. Ltd。, having the time available whilst on standby for Civil Defence, for a brief low level survey of the camp and junction. Afterwards he waited for the opportunity of further transport, either within the Inangahua area or back to communications facilities at Westport or Reefton。

Difficulties of access within the area, and other urgent demands for helicopter use, afforded opportunity for only the briefest and limited random sample appraisal of damage. However, it vas felt that enough had been learned to formulate suggestions to aid restoration within the area. it noon an available seat was taken in an Iroquois to Westport airport。 


\section{Damage to buildings}

Inangahua Junction is at the confluence of the Inangahua and Buller rivers, from which the Buller River continues to the sea. Buildings are confined to the valleys, on eroded or sedimented river terraces, or on base hillslopes. The remainder of the terrain is steep and wooded.

The settlement of Inangahua "Camp" is on a terrace between the rivers, and that of the "Junction" is $2 / 3$ mile due west on the opposite side of the Inangahua River. Together the settlements comprise a township of some 50 houses, a school, two churches, hotel, motel, petrol station, two stores and a Railway station. At the east side of the camp is an electrical power sub-station (see paper by H.C. Hitchcock)。 Most of the dwellings in the township are state owned, being the property of the various government departments of Railways, Electricity, Works and Education.

In the farmland of the rest of the area of prime damage are some 30 farm dwellings with ancillary stores, milking sheds and implement sheds; all under private ownership。

All dwellings in the area are timber framed. External walls are of timber weather board, except for two Electricity Department houses with brick veneer walls. Roofs are of galvanised iron sheeting, except for eight state owned houses having tile roofs。 Relatively few buildings had sound foundations, such as timber base plates of walls bolted to a continuous concrete foundation strip around the perimeter. The farm dwellings, and the non-state built dwellings, generally were supported by an array of free standing timber piles. Many such structures moved sideways as the timber piles folded over from vertical to horizontal. Differential movements occurred in most cases.

Severe damage occurred to unreinforced brick or concrete block chimneys, either because of inherent weakness of the material, or because the chimney bases were brittle and provided greater rigidity for lateral movements of the building structure than did the foundations. Many external chimneys collapsed completely to rubble。 Several internal chimneys with poorly bonded bricks, in addition to collapsing above the roof line, spread laterally within the confined space bulging the walls locally。

There were no buildings with masonry bearing walls, other than two farm sheds with unreinforced concrete block perimeter walls in which the mortar was effectively unbonded to the blocks. The walls disintegrated to piles of loose blocks, leaving the steel and timber interiors of the structures standing in the manner of tents.

It is not considered to be speculative to assert, that had a town with unreinforced masonry, of pre-earthquake-design-code vintage existed in the area, the incidence of damage would have been calamitous. The author, from his observations of earthquake damage elsewhere considers that the local intensity of shaking was much stronger than that which caused severe damage to the brittle building constructions of Agadir, Morocco, 1960, or Skopje, Yugoslavia, 1963.

The ordinary timber frame houses, as built in New Zealand, generally have a high level of earthquake resistance, especially if only of one storey and of a rectangular or well compartmented shape, and built on good ground. The extent of damage to such buildings in earthquakes depends upon workmanship and condition, the presence or absence of 
diagonal bracing in walls and ceiling or roof, and whether or not the building is well bolted to its foundations.

Most buildings in Inangahua had one or more deficiences in this regard. Comparable timber frame houses, though then newer in construct$i$ on were damaged in the Long Beach, California, earthquake of 1933. The pattern of damages to timber dwellings reportedly was similar - a common feature being dwellings solely supported on free standing piles which tipped over leaving the structure free to slide。

\section{Feasibility of repair}

It was apparent after the sample inspections of the morning of May 25 that repair of the Inangahua type buildings was feasible and could proceed generally as follows:

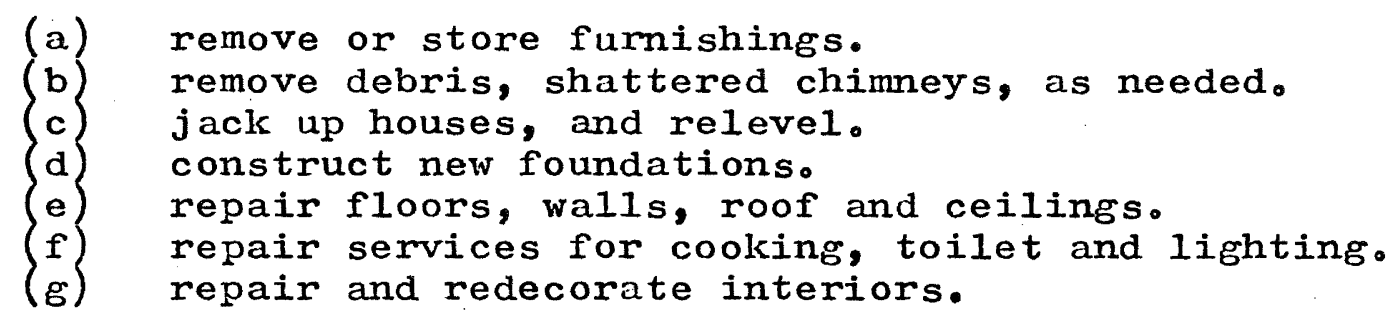

Each building would require survey and inspection, following which a brief specification outlining the reinstatement could be prepared.

\section{Access and costs}

On May 25, road access to the north and west had been lost because of slips, probably for several weeks. The remaining road access to the south, to Reefton, probably could be reopened within days, but uncertainties remained because of uncertain damage to bridges and the effect of chance weather (late Autumn) or further tremors.

It was clear that costs of reinstatement of damage would be hard to assess immediately. The uncertainties - costs for boarding and feeding workmen, costs for travelling and allowances, purchase, freight and storage of material, could be the source of a major difference between the costs of disaster repair and normal repiar - for example between the costs of reinstatement of one or a few buildings damaged by a normal privately insurable hazard such as fire, when accesses, labour and materials, remain normally available, and the reinstatement of a large group of buildings damaged by and in the circumstances of a disaster hazard。

Those aspects, together with government commitments in roading, railways, accesses, and a large portion of the buildings, pointed to the desirability of government considering Inangahua as a special area for restoration.

\section{Insurance and costs}

In New Zealand all property which is currently insured against damage by fire (with certain scheduled exceptions - eogo roads; Iand; bridges; services for water, drainage, electricity, external to the perimeter of buildings) is deemed by the Earthquase and fiar Damage ict 1944 and its subsequent regulations (see paper by J。L。GiII) to be insured under the Act to the same amount against earthquake damage。 The limit of liability of the government insurance Commission is the insured 
sum or the indemnity value, whichever is less. The excess payable by the insured for the first part of any loss is low, simply $\$ 10.00$ or one percent of the loss with a maximum of $\$ 100.00$. The Commission also has legislative authority to insure voluntarily for amounts greater than indemity value and to insure property which is excluded from the compulsory cover. However, there was no such additional voluntary cover upon property in the Inangahua area.

Within the limitation upon the Commission's liability being the indemnity value of insured buildings, and the exclusion of drains and services beyond the building perimeter, also the exclusion of uninsured property, it seemed to be clear that in many cases there could be a significant gap between the amounts of compensation legislatively payable under earthquake insurance and the actual loss or costs of repair or reconstruction.

In common with the usual procedure of insurers, the Noz. Earthquake and War Damage Commission can elect at its option to reinstate or replace the property destroyed or damaged or to pay the amount of the loss or damage; but is not bound to reinstate or replace exactly or completely, but only as circunstances permit and in a reasonably sufficient manner。 In no case is the Commission bound to spend more in reinstatement or replacement than it would cost to reinstate or replace the property as it was at the time of the occurrence of the loss or damage, nor more than the sum insured.

In this circumstance, and for the area of heavy damage, the author envisaged, for the restoration of dwellings and essential farm buildings at least, a combination of insurance payments and low interest loans according to need as follows:

\section{(a) insurance payable legislatively by the Commission. \\ (b) Low interest loans, repayable in $x$ years, available from an agency of govermment, to cover the gap between insured loss and actual loss or the cost of an approved repair or approved reconstruction.}

The author had been impressed, during three weeks spent in Agadir, Morocco, in 1966 to observe the procedure of restoration, to learn that eventually, though there was no insurance, a procedure for administering such low interest loans had been carefully developed by the High Commission for Reconstruction of Agadir.

In Inangahua in late May, with the approaching winter, and the fact that the heavily damaged area was being evacuated, there seemed to be reason and justice in enabling farmers to return to habitable houses as quickly as practicable, both to enable them to resume their work of livelihood and to use an opportunity for practice in disaster repair.

It is the preference of the Commission, and simplest generally to make cash settlements for losses. For within the designated special area however, the author promptly recommended that the Commission reinstate any damaged insured buildings, except where the owner desired a cash settlement for the insured loss.

\section{Agency for restoration of buildings}

The Parthquake and War Damage Act 1944 and Regulations 1956 confer upon the Conmission the liability to make good (by payment or reinstatement or repair, at its option) and establish the basic rules in which it works. The Commission has no authority to reinstate uninsured property。 
Some border line of doubt as to its responsibilities in the procedure of reinstatement can exist where property is under-insured, where the cost of restoration is greater than indemnity value, or where integral components of function (e。go sewerage disposal from a house) are not insured. However, such border line doubts would seem to be primarily procedural in cases where an owner has requested or consented to reinstatement by the Commission, and the Commission incurs no financial liability additional to the sum payable under insurance, That condition could be met where the owner makes contribution for the agreed excess cost, either directly or by means of a loan advanced to and repayable by the owner.

In this situation, and especially in view of the heavy commitment by the government in roading, works, and many houses, the author chose to suggest that the Ministry of Works be made the agent of the Commission in restoring damaged insured property in the area, by engaging the necessary contractors and in supervising the repair works. It was felt, also, that the Ministry of Works could collaborate with whatever agency of government might make or guarantee loans, thus, in effect, having one organisation in responsible field charge of the sequence and extent of operations, with advice upon priorities from the County Council。

At noon on May 25, from Westport, the author by telephone sought and obtained the permission of the secretary of the Earthquake Commission to make such a suggestion to the County Council and to representatives of government visiting the area that afternoon.

\section{Ministerial visit}

After noon on May 25 the author joined a helicopter at Westport carrying the Hon. Mr Seath and the Hon. Mr Kinsella, (Deputising also for the Hon. Mr Rae, chairman of the Earthquake and War Damage Commission) for a flight over Inangahua and thence to Reefton. At Reefton the Ministers were received by the Civil Defence Controller and his staff, and received a verbal report on Civil Defence. Subsequently the author advanced his suggestion firstly to the County Clerk (also Civil Defence Controller) and the County Chairman, and secondly jointly to the Ministers.

The suggestion was accepted. Upon matters of detail, the author suggested that the Ministry of Vorks be asked to provide:

(a) Two competent building overseers to work with the local authority and residents in letting verbal or written contracts for repair or reinstatement of damaged privately owned dwellings in Inangahua。

(b) A third overseer to work with an insurance assessor as a team to record assessments made. (One of the three overseers to take full local responsibility after briefing)。

(c) Or arrange for, two or three building contractors with men, plant and materials capable of repairing 20 houses each with dispatch。

The author was asked to convey these proposals to the Ministry of works. In the late afternoon he travelled to Greymouth with the local resident engineer, Mr J. Douglas, of the Ministry of Works, and in the evening of May 25 spolie by telephone with the assistant District Comissioner of Works in Christchurch, and sent a confirmatory telegram stating the requests。 


\section{Ministry of Works services}

At noon on May 26, two building overseers of the Ministry of Works, Mr H. Yeatman and Mr B. Mould, reported at Civil Defence headquarters in Reefton, and a helicopter entry with them was made to Inangahua. Several houses were entered to appraise the type of damage, the feasibility of repair, and the problems of access.

In the evening the author, after discussions with Mr Yeatman, sent a further telegram to the Christchurch District Commissioner of Works outlining:

(a) A suggested composition of each of the two contractor's parties。

(b) Information that the hall and a church were available at Inangahua for an immediate camp - then the first state houses to be repaired could be used for interim accommodation of workmen。

(c) Advice received in Reefton that the Army had agreed to provide a field kitchen and meals for contractors employees for one month.

The work of further damage surveys was partially interrupted at noon on May 27 when Mr Yeatman and the writer flew to Vellington to attend a meeting (see paper by $A_{0}$ Peart)。 The further detailed survey of buildings was continued by Ministry of Works officers (see paper by $H_{0} W_{0}$. Yeatman) and administration of the restoration work was entrusted to an interim Ministry of Works residency (see paper by $S_{\circ} G$ o Hamblett and $H \circ W \circ$ Yeatman)。

\section{Personal effects in houses}

The question of safety of personal effects in houses, and of possible health hazards from decaying foodstuffs in the evacuated dwellings was discussed at a meeting of the Civil Defence Committee on May 26. The police undertook the salvaging and safeguarding of personal effects, and the supervision of storage of furnishings necessarily removed temporarily to enable repairs of buildings to be commenced.

\section{Insurance assessments}

The author recommended on May 25 the appointment of one insurance assessor full time in Inangahua for a month, at least, and firstly recommended Mr Po Lambert (who withdrew after one day, for family health reasons) and subsequently as a replacement $M_{x} J_{0} W_{0}$ Lowery of Bird and Lowery Ltd., insurance assessors。

Assessment of losses of contents of buildings and personal effects proceeded in the normal manner. For buildings, the assessor and the insured owner had the assistance of the Ministry of Works in determining an appropriate extent of repair, and in supervising the cuality of repair work where owners elected to have reinstatement planned and supervised by the Ministry。

Severe and unforseen delays occurred in obtaining information of their insurances from owners, and in obtaining the alternative advice or confirmatory information of insurances from private fire insurers who 
collect for the commission the earthquake and war damage insurance premium (and who are obligated to give certificates of currency of insurance upon request). Tenders for the reinstatement of dwellings, and also advice or confirmation of insurance covers was received progressively and slowly, and some time elapsed before both were available for any one property, so that reinstatement of privately owned buildings could be cominenced.

\section{Liaison with insured persons}

Although the severely damaged area was lightly populated, it was clear initially that considerable work and effort were required, and warranted, in negotiating with owners, in being of assistance to them in seeking and giving information relevant to reinstatement and insurance problems. This was no one person's or organisation's clear responsibility, and the field extended from welfare to technical aspects.

Many of the people who had been evacuated from the area of prime damage were in a state of emotional or mental shock. They had important issues sometime to face:- of whether or not to return, and whether or not they could afford to, apart from concem about the mysterious continuing aftershocks (to be expected for a shallow $M=7$ earthquake). As envisaged there was immediate need for a field interviewing group, whose prime function was to explain things patiently, to note decisions made but in no case to pressure anyone to make hastily a decision of which he or she was unsure. It was anticipated that where people were undecided several visits or interviews would be necessary before they might properly make decisions for their future.

After discussion with the Civil Defence Controller, a school teacher, Mr $W_{0} K_{0}$ Roundhill, who had volunteered, was appointed by the Civil Defence Committee on the evening of May 26 as Civil Defence liaison officer. The liaison officer began work in co-operation with the insurance assessor and a Ministry of Works overseer. However when schools reopened three days later, Mr Roundhill was obliged to resign. Then at a further Civil Defence meeting the Rev. M. Smart volunteered to be his replacement. Mr Smart was appointed chairman of a three man interviewing committee (see paper by Revo M. Smart) and he and his committee members of Mr Lowery (assessor) and $\mathrm{Mr}$ Yeatman (senior buildings overseer) did invaluable and necessarily time consuming work in the field.

\section{Departmental co-operation}

A government interdepartment meeting in Vellington was held on the afternoon and evening of Monday May 27, in consequence of which advisory committees to aid the local authorities were formed. On Thursday May 30 the District Commissioner of Works, from Christchurch, reported to the Civil Defence Committee in Reefton upon the formation and work of the committees and upon the role of the Ministry of Works in establishing an interim residency (see paper by $A$. McG. Peart)。

\section{Lessons learned}

Earthciakes occur quite unexpectedly in time and location. Thus advance planning for earthquake disaster must be elastic enough to meet possible contingencies. The author feels that a prime compliment for immediate action and efficiency is due to the civil defence organisation of Inangahua County and to its controller, Mr Moore. 
The lessons which are to be learnt for the future, for some conceivable larger or more serious earthquake disaster, derive mainly, in the Inangahua earthquake, from the stage of transfer of activity and associated responsibility from the first aid operation of civil defence to the ultimate task of restoration. That is a complex activity upon which the views of many persons and authorities will impinge。 